\title{
Electrochemical Evaluation of Pipelines Materials of the Miravalles Geothermal Field in Costa Rica
}

\author{
G. Tres, ${ }^{\text {a, }}$ E. Saborío, ${ }^{\mathrm{a}}$ J. Urruchurtu, ${ }^{\mathrm{b}}$ J. Malo ${ }^{\mathrm{b}}$ \\ ${ }^{a}$ Instituto Costarricense de Electricidad, Costa Rica \\ ${ }^{b}$ Instituto de Investigaciones Electricas, Mexico
}

Received 22 March 2007; accepted 27 July 2007

\begin{abstract}
In the past, mechanical properties have been the main criteria for selecting materials at the Miravalles Geothermal Field. Consideration of the corrosion resistance has been a secondary concern. The goal of this study was to determine the uniform corrosion rate of carbon steels currently used on pipelines (ASTM A 53, ASTM A515, ASTM A234 and API-5L) and compare this rate with the ASTM A-36 standard. The first step was the development of laboratory electrochemical and weight loss experiments. Ultrasonic thickness measurements of pipes for brine, steam and liquid-steam lines, in both straight and curve sections, showed negligible lost in material over the seven year period they have been on operation. The electrochemical study involved polarization curve analysis and corrosion rate measurements by Linear Polarization Resistance (LPR) and Electrochemical Noise Measurements (ENM). Electrochemical cells include triple and conventional testers (SCE as reference and platinum electrode as auxiliary) using brine degassed with nitrogen at $93 \pm 2{ }^{\circ} \mathrm{C}$. According to the results, the ASTM-A36 has a similar general corrosion rate to those currently used on pipelines.
\end{abstract}

Keywords: linear polarization, electrochemical noise, geothermal brine, steel carbon.

\section{Introduction}

The Miravalles, Costa Rica, Geothermal Field represents one of the most important resources of electric power generation of the country. In fact, it produces more than $137 \mathrm{MW}$, approximately $10 \%$ of the total energy production [1]. It is a liquid-dominated high temperature $\left(241{ }^{\circ} \mathrm{C}\right)$ geothermal reservoir with moderate salinity, compared to other geothermal brines like those from California [2,3]. Table 1 shows the composition of the brine. Due the growing awareness of the effects of corrosion phenomenon, design engineers are relying on corrosion studies. These studies allow engineers to obtain the best

\footnotetext{
* Corresponding author. E-mail address: Gtres@ice.go.cr
} 
performance during structure's life time, make proper materials selection, and choose the most economical metals and most convenient pipeline thickness. This report includes laboratory tests of corrosion rates by Linear Polarization Resistance (LPR), Electrochemical Noise Measurements (ENM) and weight loss method in static brine at $93{ }^{\circ} \mathrm{C}$ from a typical well, "PGM8". Linear Polarization Resistance technique is widely employed and the relevant theoretical relationships are shown bellow:

$$
I_{\text {corr }}=\frac{B}{R_{p}}
$$

where

and

$$
B=\frac{\beta a \beta c}{2.30(\beta a+\beta c)}
$$

$$
\frac{1}{R_{p}}=\frac{\Delta I}{\Delta E}
$$

When the system is polarized a few milivolts from the corrosion potential $(\Delta \mathrm{E}<$ $20 \mathrm{mV}$ ), the measured current $\Delta \mathrm{I}$, allows the calculation of $\mathrm{R}_{\mathrm{p}}$. The constant $\mathrm{B}$, is related to the anodic and cathodic Tafel slopes, $\beta_{\mathrm{a}}$ and $\beta_{\mathrm{b}}$. The value of $\mathrm{B}$ is relatively constant in spite of the wide variation of $\beta_{\mathrm{a}}$ and $\beta_{\mathrm{c}}$ with time [4], because the changes affect the numerator about the same as the denominator of B. In fact, for carbon steels B fall within the range of 10 to $45 \mathrm{mV}$ [5]. Generally, the LPR technique is considered suitable to predict corrosion rates in the laboratory within a factor of 2 [5].

Electrochemical Noise Measurements, ENM, record the fluctuations in current and potential generated by corroding metals. Iverson first reported these phenomena in 1968 [6]. ENM can be converted to corrosion rates by calculating noise resistance:

$$
R_{n}=\frac{\sigma_{v}}{\sigma_{I}}
$$

where, $\sigma_{\mathrm{V}}$ and $\sigma_{\mathrm{I}}$ are standard deviations of the potential and current and $\mathrm{R}_{\mathrm{n}}$ is equivalent to $R_{p}$ [7]. The ENM analysis method has been highly effective for determining corrosion rates for systems exhibiting general corrosion rates below $1.3 \mathrm{~mm} /$ year [8]. The goal of this study was to determine the general corrosion of the metals currently used on pipelines used at Miravalles Geothermal Field and to compare them against ASTM A-36. The next step in this investigation will be in-line electrochemical corrosion monitoring.

\section{Experimental procedure}

The tests were conducted in a glass electrochemical cell, EG\&G model, at $93 \pm 2$ ${ }^{\circ} \mathrm{C}$, with a condenser to avoid liquid evaporation. The cell was filled two-thirds 
with PGM 8 brine, initial $\mathrm{pH}=7.80 \pm 0.08$. Nitrogen was continuously bubbled through to maintain maximum deoxygenated conditions. The oxygen in solution was calculated by the Winkler method [9]. The carbon steels evaluated were ASTM A 53, ASTM A515, ASTM A234, ASTM A36 and API-5L, and all electrochemical experiments were made with an 8 AC potentiostat, ACM Instruments.

The corrosion rate experiments by LPR and ENM were run using three identical electrodes assembled in chemically inert polyester resin to avoid $\mathrm{pH}$ variation. Where electrochemical study involved polarization curves, analyses were run using simple test, with $\mathrm{SCE}$ or $\mathrm{Ag} / \mathrm{AgCl}$ sat. as reference, and a platinum wire as a counter electrode. The metal electrodes were polished with a 600-grit sandpaper and $10 \mu \mathrm{m}$ alumina finish. Both test electrode configurations are shown in Fig. 1. The duration of each LPR experiment was 3-5 days, to allow the corrosion rates to approach a steady state. The LPR measurements were made at $\pm 10 \mathrm{mV}$ from $E_{\text {corr, }}$ and the scan rate at $80 \mathrm{mV} / \mathrm{min}$. On the final day of the experiment the corrosion potential $\mathrm{E}_{\mathrm{corr}}$ and $\mathrm{pH}$ were registered to consider possible corrosion products from Pourbaix diagrams $[10,11,12]$. The ENM were made after LPR, a single data set consisted of 1024 points $(1 \mathrm{mHz})$ collected at a rate of 1 point per second.

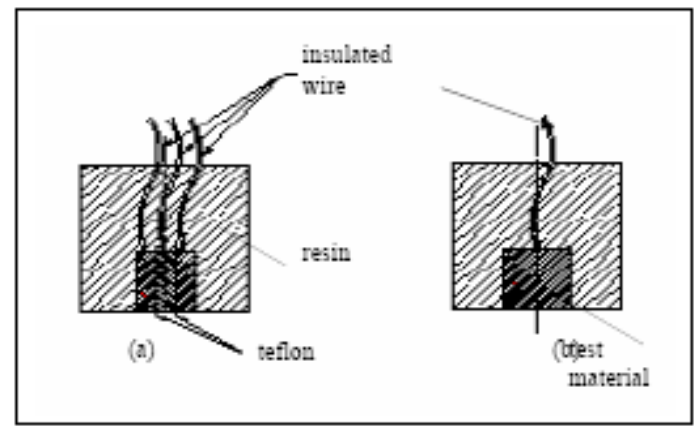

Figure 1. Testers used in electrochemical

Ultrasonic measurements were made with a Krautkrämer instrument and a gauge DA205 for high temperature surfaces. The samples for general corrosion weight loss measurements were 2.0 by $2.0 \mathrm{~cm}$ and $1 \mathrm{~mm}$ thick. During the weight loss tests, the specimens were suspended in the brine from a holder made of wire coated with a plastic. The chemical cleaning procedure for removal of corrosion products is described in c.3.1 of the standard ASTM G1-90 standard [13]. This test lasted 285 hours, and three specimens were included. For examination of the samples a Hitachi S-2360N scanning electron microscope and a Nikon SMZ-10 stereomicroscope were used.

\section{Discussion and results}

Corrosion rates by different methods are given en Table 2. Overall, the results determined by both, electrochemical and weight loss methods were in good agreement. These results suggest that electrochemical methods are acceptable as 
a direct measure of the corrosion rate at the pipelines. In some cases, the agreement between weight loss and linear polarization data was considerably better than the factor of 2 mentioned by others [14], e.g., A 515 and A 53 steels. The differences between LPR and weight loss data were considerably less than one order of magnitude, and only in the case of A36 was a factor of 5 obtained. Since the weight loss data are accurate, they are more suitable to compare the material performance. As it was expected, the general corrosion rate for all the carbon steels tested was of the same order of magnitude due to their similar composition, as shown in Table 2.

Table 1. Some important characteristics of geothermal brine of PGM 8 well.

\begin{tabular}{|c|c|c|c|}
\hline Constituent & May 94, ppm & September 97, ppm & August 98, ppm \\
\hline $\mathrm{Na}^{+}$ & 2150 & 2431 & 2530 \\
\hline $\mathrm{K}^{+}$ & 268 & 318 & 325 \\
\hline $\mathrm{Ca}^{++}$ & 61 & 79 & 91 \\
\hline $\mathrm{Mg}^{++}$ & 0.21 & 0.14 & 0.1 \\
\hline $\mathrm{Cl}^{-}$ & 3575 & 4227 & 4420 \\
\hline $\mathrm{SO}_{4}{ }^{+}$ & 50 & 40 & 45 \\
\hline $\mathrm{HCO}_{3}$ & 85 & 19 & 19 \\
\hline $\mathrm{SiO}_{2}$ & 635 & 607 & 580 \\
\hline $\mathrm{CO}_{2}{ }^{a}$ & 80.15 & 56.09 & 69.94 \\
\hline $\mathrm{H}_{2} \mathrm{~S}^{\mathrm{a}}$ & 0.78 & 0.83 & 1.82 \\
\hline $\mathrm{Parameter}$ & $\mathrm{May} 94$ & September 97 & August 98 \\
\hline $\mathrm{TDS}(\mathrm{ppm})$ & 7228 & 8424 & 8455 \\
\hline $\mathrm{pH}$ & 8.15 & 8 & 7.72 \\
\hline Cond. $\left(\mathrm{S} / \mathrm{cm}^{2}\right)$ & $\mathrm{b}$ & 12971 & 13050 \\
\hline T media $\left({ }^{\circ} \mathrm{C}\right)$ & 238 & 242.2 & 241.4 \\
\hline
\end{tabular}

${ }^{\mathrm{a}}$ Units are mmoles/Kg. ${ }^{\mathrm{b}}$ Not determined.

Table 2. General corrosion rates obtained by different methods.

\begin{tabular}{|c|c|c|c|}
\hline Carbon steel & $\begin{array}{l}\text { Rate/LPR }{ }^{\mathrm{a}} \\
\text { (mm/year) }\end{array}$ & $\begin{array}{l}\text { Rate/ENM } \\
\text { (mm/year) }\end{array}$ & $\begin{array}{l}\text { Rate/gravimetry } \\
(\mathrm{mm} / \text { year }) \pm \sigma_{\mathrm{n}-1}\end{array}$ \\
\hline ASTM A 36 & 0.273 & 0.421 & $0.051 \pm 0.002$ \\
\hline ASTM A 53 & 0.065 & 0.023 & $0.057 \pm 0.006$ \\
\hline ASTM A 234 & $0.146^{b}$ & 0.108 & $0.055 \pm 0.003$ \\
\hline API 5L & 0.196 & 0.467 & $0.07 \pm 0.01$ \\
\hline ASTM A 515 & 0.089 & 0.039 & $0.058 \pm 0.002$ \\
\hline
\end{tabular}

The typical corrosion rate data as a function of time are shown in Fig. 2. In most cases, the corrosion rates did not approach a lower steady rate, but the range of variation was small. The A 234 steel was placed in the electrochemical cell two days before the measurements were made and only data collected over two days are shown. The corrosion rates from LPR did not approach a lower steady rate in 
four days, while in the weight loss samples it took eleven days; thus the weight loss data were lower than for LPR.

The results of general corrosion rates by LPR are summarized in Table 3. The Tafel slopes and the weight loss data were used to calculate B values; they are also shown in Table 3 . B values obtained from the Tafel vary very little from the value $B=0.026 \mathrm{~V}$ utilized in the calculations and suggested in the literature [15]. In the case of gravimetry the range of variation in B is larger. Since this is a more accurate method, a more exhaustive study should be considered to examine how $\mathrm{B}$ affects the value of corrosion rate by this technique.
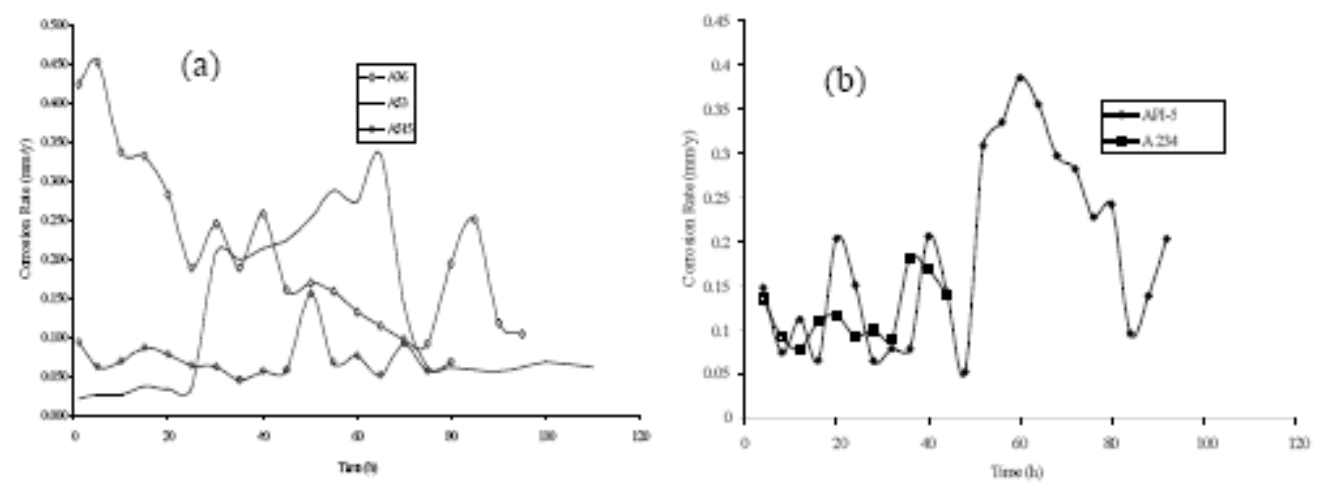

Figure 2. General corrosion rate by LPR of carbon steels in PGM8.

Table 3. General corrosion rate by LPR. Variation of B.

\begin{tabular}{|c|c|r|c|c|}
\hline Carbon steel & $\begin{array}{c}\text { Rate, } \mathrm{mm} / \mathrm{y} \\
\mathrm{B}=0.026, \mathrm{~V}\end{array}$ & $\begin{array}{c}\text { Rate, } \mathrm{mm} / \mathrm{y} \\
\mathrm{I}=\beta \mathrm{a} / 2.3 \mathrm{Rp}\end{array}$ & $\begin{array}{c}\mathrm{B}, \text { from Tafel } \\
\text { data, } \mathrm{V}\end{array}$ & $\begin{array}{c}\mathrm{B} \text {, from corrosion } \\
\text { data, } \mathrm{V}\end{array}$ \\
\hline ASTM A 36 & 0.215 & 0.287 & 0.027 & 0.008 \\
\hline ASTM A 53 & 0.06 & 0.084 & $\mathrm{a}$ & 0.023 \\
\hline ASTM A 234 & 0.109 & 0.122 & 0.030 & 0.014 \\
\hline API 5L & 0.226 & 0.353 & 0.022 & 0.014 \\
\hline ASTM A 515 & 0.083 & 0.109 & 0.026 & 0.021 \\
\hline
\end{tabular}

${ }^{\mathrm{a}}$ Not tested.

Field ultrasonic thickness results are shown in Table 4; they are the average of three measurements at eight points around the pipe. Thickness data were greater than the nominal values, because suppliers offer $\pm 12 \%$ in thickness, and usually it is at the up limit. Although the ultrasonic measurements do not allow estimating the actual material loss, it is possible to confirm that it has been negligible after 7 years in service. Ultrasonic measurement will allow the thickness monitoring and identification of any localized attack around the pipeline, too, especially because there are different fluid patterns.

The corrosion rates founded for carbon steels are much lower than those observed by others $[16,17]$. This is believed to be due to higher $\mathrm{pH}$ of the PGM8 brine, because rates typically increase as the $\mathrm{pH}$ decreases. Harrar et al. [16] studied corrosion rates in the $\mathrm{pH}$ range of 2.3 to 3.4 at $100{ }^{\circ} \mathrm{C}$ and measured rates were greater than $2.5 \mathrm{~mm} / \mathrm{y}$ for carbon steels. These results are very similar to 
those obtained in this study for A36 and A53, shown in Table 5. In fact, the steel most affected by the $\mathrm{pH}$ was A53 since the rate increased 34 times when compared to that obtained at brine $\mathrm{pH}=7.8$, Table 2. For API-5L, A515, A36 and $\mathrm{A} 234$, this increase factor was 2, 5, 13 and 11, respectively, close to an order of magnitude in most cases.

The concentration of oxygen at $95^{\circ} \mathrm{C}$, approximated by the Winkler method [9], is lower than $13 \mathrm{ppm}$, whereas at $40^{\circ} \mathrm{C}$ it is near to $22 \mathrm{ppm}$. When the oxygen increases, the cathodic reaction is more affected by mass transfer and, as it is shown in Table 5, little increases of oxygen by lowering the temperature produce higher corrosion rates. Table 5 also shows that API-5L was the steel least affected by decrease in $\mathrm{pH}$ and increase in oxygen. The effect of $\mathrm{pH}$ and oxygen on corrosion rate was also confirmed with polarization curves for all the steels, and cathodic control of the reaction was obtained, Fig. 3. Overall, these results confirm the importance of controlling the $\mathrm{pH}$ and the concentration of oxygen in carbon steels of pipelines.

Table 4. Ultrasonic thickness measurements of Miravalles geothermal field pipes.

\begin{tabular}{|c|c|c|c|c|c|}
\hline Measurement & Carbon steel & Fluid & $\begin{array}{c}\text { Nominal } \\
\text { thickness, } \\
\mathrm{mm} \pm 12 \%\end{array}$ & $\begin{array}{c}\text { Thickness, } \\
\text { Aug-99 } \\
\mathrm{mm} \pm \sigma_{\mathrm{n}-1}\end{array}$ & $\begin{array}{c}\text { Thickness, } \\
\text { Feb-00 } \\
\mathrm{mm} \pm \sigma_{\mathrm{n}-1}\end{array}$ \\
\hline P1 & ASTMA515 & two-phase & 9.52 & $10.3 \pm 0.2$ & $10.12 \pm 0.09$ \\
\hline P2, curve & ASTM A234 & two-phase & 19.6 & $19.0 \pm 0.3$ & $18.6 \pm 0.3$ \\
\hline P3 & ASTM A515 & two-phase & 9.52 & $9.9 \pm 0.2$ & $9.9 \pm 0.2$ \\
\hline P4, curve & ASTM A234 & steam & 12.7 & $13.0 \pm 0.2$ & $12.9 \pm 0.2$ \\
\hline P5 & ASTM A515 & steam & 12.7 & $13.4 \pm 0.1$ & $13.3 \pm 0.2$ \\
\hline P7 & ASTM A53 & brine & 7.52 & $8.6 \pm 0.2$ & $8.5 \pm 0.2$ \\
\hline P8, curve & ASTM A234 & brine & 9.52 & $10.9 \pm 0.7$ & ${ }^{a}$ \\
\hline P9 & API 5L & two-phase & 12.7 & $13.0 \pm 0.1$ & $12.8 \pm 0.1$ \\
\hline P10 & API 5L & two-phase & 12.7 & $13.6 \pm 0.2$ & $13.5 \pm 0.2$ \\
\hline
\end{tabular}

${ }^{\mathrm{a}}$ Not tested.

Table 5. Effect of oxygen concentration and $\mathrm{pH}$ in corrosion rates, by LPR.

\begin{tabular}{|c|c|c|}
\hline $\begin{array}{c}\text { Carbon } \\
\text { steel }\end{array}$ & $\begin{array}{c}22 \mathrm{ppm} \mathrm{O}_{2}, 40{ }^{\circ} \mathrm{C} \\
\text { Rate }(\mathrm{mm} / \text { year })\end{array}$ & $\begin{array}{c}\mathrm{pH}=3.07 \\
\text { Rate }(\mathrm{mm} / \text { year })\end{array}$ \\
\hline ASTM A 36 & 0.521 & 2.78 \\
\hline ASTM A 53 & 1.46 & 2.05 \\
\hline ASTM A 234 & 0.493 & 1.24 \\
\hline API 5L & 0.428 & 0.525 \\
\hline ASTM A 515 & 0.283 & 0.401 \\
\hline
\end{tabular}

Table 6 shows the corrosion potential of the all carbon steels, versus standard hydrogen electrode (SHE), and the $\mathrm{pH}$ after the LPR tests. The corrosion films are 
also predicted from high temperature Pourbaix diagrams. Corrections in potential values at high temperatures were based in data reported by Danielson [18].

The weight loss samples had both, non-adherent and adherent corrosion products. The less adherent products were greenish and an adherent black layer underneath (wet samples), chemical washings could remove only the latter. Only in the case of A515 mostly adherent products were formed. Beverskog and Puigdomenech [11] found that iron in de-aerated aqueous solution becomes passivated by the formation of a protecting layer of magnetite, $\mathrm{Fe}_{3} \mathrm{O}_{4}$. Although, at $100{ }^{\circ} \mathrm{C}$ this product is predicted from the Pourbaix diagrams [11], it is near the area of $\mathrm{Fe}^{2+}$ soluble products [11]. Only in the case of A515 steel was magnetite and hematite products predicted. Although the theoretical predictions seem to coincide with the observations, the analyses by difractometry will be presented in another report.

Table 6. Steady-state corrosion potentials on SHE and predicted phases from Pourbaix diagrams.

\begin{tabular}{|c|c|c|c|c|c|}
\hline Carbon steel & $\mathrm{pH}$ & $\begin{array}{c}\mathrm{E}_{\text {corr, }} \mathrm{V} \\
100{ }^{\circ} \mathrm{C}\end{array}$ & $\begin{array}{c}\text { Predicted phases, } \\
100{ }^{\circ} \mathrm{C}\end{array}$ & $\begin{array}{c}\mathrm{E}_{\text {corr, }} \mathrm{V} \\
250{ }^{\circ} \mathrm{C}\end{array}$ & $\begin{array}{c}\text { Predicted } \\
\text { phases, } 250{ }^{\circ} \mathrm{C}\end{array}$ \\
\hline ASTM A 36 & 7.60 & -0.475 & $\mathrm{Fe}^{2+}, \mathrm{Fe}_{3} \mathrm{O}_{4}$ & -0.665 & $\mathrm{Fe}_{3} \mathrm{O}_{4}$ \\
\hline ASTM A 53 & 7.91 & -0.475 & $\mathrm{Fe}^{2+}, \mathrm{Fe}_{3} \mathrm{O}_{4}$ & -0.665 & $\mathrm{Fe}_{3} \mathrm{O}_{4}$ \\
\hline ASTM A 234 & 7.71 & -0.464 & $\mathrm{Fe}^{2+}, \mathrm{Fe}_{3} \mathrm{O}_{4}$ & -0.725 & $\mathrm{Fe}_{3} \mathrm{O}_{4}$ \\
\hline API 5L & 7.50 & -0.535 & $\mathrm{Fe}^{2+}, \mathrm{Fe}_{3} \mathrm{O}_{4}$ & -0.725 & $\mathrm{Fe}_{3} \mathrm{O}_{4}$ \\
\hline ASTM A 515 & 7.92 & -0.350 & $\mathrm{Fe}_{3} \mathrm{O}_{4}, \mathrm{Fe}_{2} \mathrm{O}_{3}$ & -0.540 & $\mathrm{Fe}_{2} \mathrm{O}_{3}$ \\
\hline
\end{tabular}

Cyclic voltametric polarization does not indicate passivation and therefore of pitting for any of the steels, a typical curve is shown in Fig. 4. Although for this study a localized corrosion analysis was not carried out, it can be stated that the LPR probes as well as those for gravimetry for A53 showed spherical zones with accumulation of corrosion products underneath, on which localized corrosion in most cases could be observed, Fig. 5. On the other hand, the probes of A515 steel showed much more adherent products than the other steels, Fig. 6. All the samples for LPR showed crevice corrosion on the edge of the metal-resin interface, presumably through a mechanism of differential aeration.

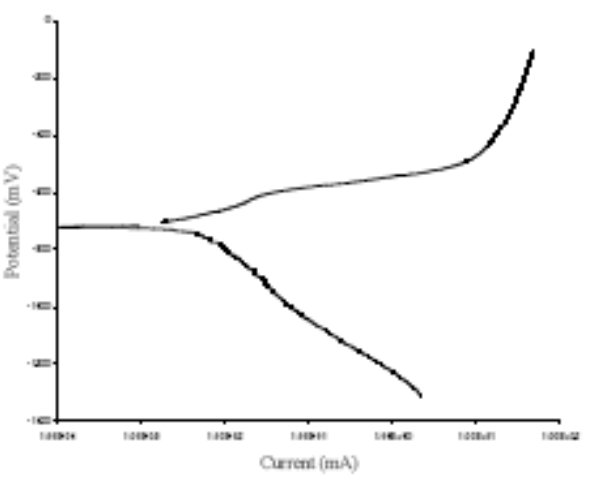

Figure 3. Polarization curve of ASTM A 234 in PGM8 brine, at $90^{\circ} \mathrm{C}$.

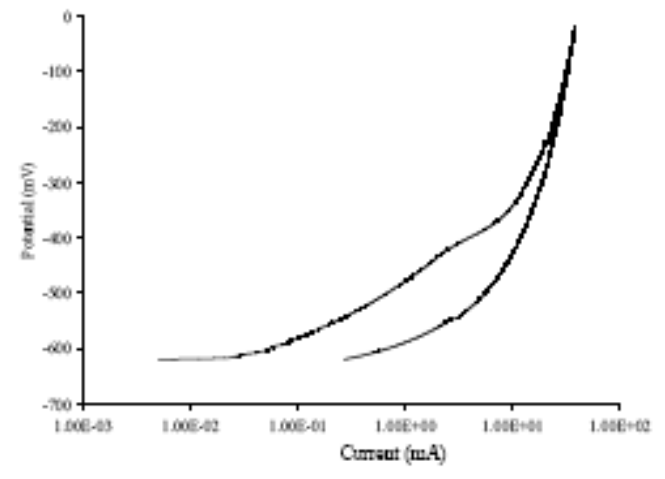

Figure 4. Anodic cyclic voltammetry of ASTM A 515 in PGM8 brine, at $90^{\circ} \mathrm{C}$. 


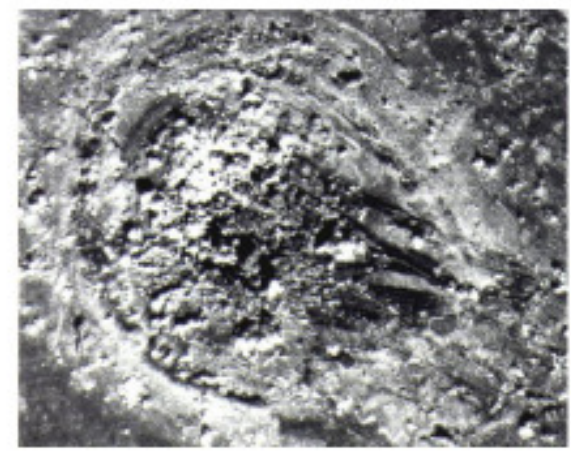

Figure 5. Corrosion in A53 steell. $40 \mathrm{~A}$.

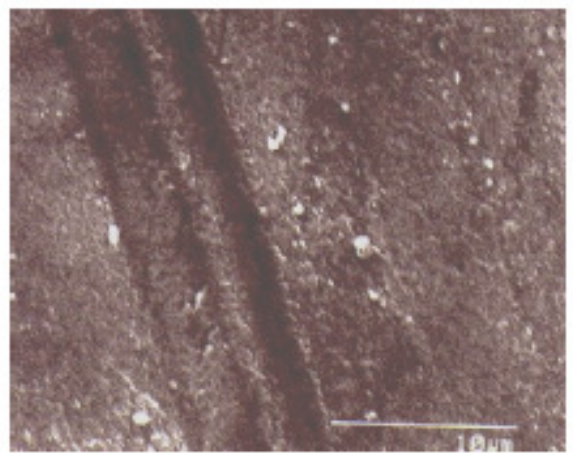

Figure 6. Corrosion in A 515. 4X A.

The laboratory tests represented a single environment whereas the field tests represented three distinct process environments distinguished by temperature, pressure, fluid phases, composition, turbulence and scaling tendency. Because of these differences the laboratory results were not expected to reproduce accurately the field behavior. On the other hand they provided useful data for interpreting carbon steel performance in the field and for further on-line studies.

\section{Conclusions}

The results for the generalized rate of corrosion using the three methods LPR, EMN and gravimetry have good correlation, which suggests that the electrochemical techniques are appropriate for on-line monitoring of steel pipelines at the Miravalles Geothermal Field. Considering the gravimetric method, it obtained corrosion rates that were very similar for all the steels. Therefore, A36 can be considered reliable in the material selection studies for future geothermal projects in the region.

The rate of corrosion of the carbon steel, in the study conditions, are dominated by a cathodic control mechanism where small increases in oxygen of the order of $\mathrm{ppm}$ and values of $\mathrm{pH}=3.07$ showed increase in the rate of corrosion of up to one order of magnitude. The ultrasonic measurements indicate a negligible wear off of the pipelines which agrees with the good performance reported by the Department of Construction and Maintenance of the Miravalles Geothermal Project. These and future laboratory and field studies will allow to make better corrosion thickness recommendations in future projects like Tenorio Geothermal Project.

\section{Acknowledgment}

This work had assistance by the Center of Electronic Microscopy of the University of Costa Rica. Appreciation is extended to Construction and Design Divisions of Miravalles for supply the samples for this study. 


\section{References}

1. ICE, UEN Producción, Plantas Hidroeléctricas y Termoeléctricas en Servicio, Agosto, 1998.

2. W.T. Lee, D. Kramer, Geothermal Scaling and Corrosion, ASTM STP 717, New Orleans, 1979. p. 142-154.

3. S.D. Cramer, J.P. Carter, Geothermal Scaling and Corrosion, ASTM STP 717, New Orleans, 1980. p. 113-141.

4. F. Mansfeld, Corrosion 29 (1973) 397.

5. L. Callow, J. Richardson, J. Dawson, British Corrosion Journal 11 (1976) 123-139.

6. W.P. Iverson, J. Electrochem. Soc. 115 (1968) 617-618.

7. D.A. Eden, K. Hladky, D.G. John, NACE Corrosion/86 Conference. NACE, Houston, TX, 1986. p. 274.

8. D. Reichert, Electrochemical Noise Measurement for Corrosion Applications, ASTM STP 1277, West Conshohocken, PA,1996. pp.79-89.

9. R.H. Perry, C.H. Chilton, Manual del Ingeniero Químico, $5^{\text {th }}$ ed, McGrawHill, Mexico, 1987. p.3-103.

10. M. Pourbaix, Atlas of Electrochemical Equilibria in Aqueous Solutions, $1^{\text {st }}$ ed, National Association of Corrosion Engineers, Houston, Texas. 1974. p. 312-313.

11. B. Beverskog, I. Puigdomenech, Corros. Sci. 12 (1996) 2121-2133.

12. D.D. MacDonald, Geothermal Scaling and Corrosion, ASTM STP 717, New Orleans, 1979. p. 10-22.

13. Standard Practice for Preparing, Cleaning, and Evaluating Corrosion Test Specimens, ASTM G 1-90, Vol. 03.02, 1993. p. 33-39.

14. M. Fontana, R.E. Staehle, Advances in Corrosion Science and Technology, Vol. 6, Plenum Press, New York, 1970. p. 163-262.

15. J.A. Gonzalez, Control de la Corrosion: Estudio y Medida por Técnicas Electroquímicas. Madrid, 1989. p.101-133.

16. J. Harrar, R. McCright, A. Goldberg, Field Electrochemical Measurements of Corrosion Characteristics of Materials in Hipersaline Geothermal Brines, Report UCRL-52376, Calif. 1977.

17. D. Shannon, Corrosion of Iron-Base Alloys Versus Alternative Materials in Geothermal Brines, Report PNL-2456. Battelle Pacific Northwest Laboratories, 1977.

18. M.J. Danielson, Geothermal Scaling and Corrosion, ASTM STP 717, New Orleans, 1980. p. 41-56. 